\title{
Penggunaan Media e-Modul untuk Meningkatkan Kemampuan Analisis Hubungan Kuat Medan Magnetik dengan Trainer Motor Listrik
}

\author{
Ihtiari Prastyaningrum, Jeffry Handhika \\ Universitas PGRI Madiun \\ Madiun, 63118, Indonesia \\ Email:ihtiari.prastya@unipma.ac.id
}

\begin{abstract}
Media e-Modul berbasis smartphone merupakan salah satu jenis modul yang dapat digunakan sebagai media pembelajaran. Pada penelitian ini telah dikembangkan media e-Modul untuk mata kuliah Teori Medan. Fokus yang diambil adalah materi Hukum Biot-Savart. Hukum Biot-Savart merupakan salah satu dasar untuk mempelajari tentang kuat medan magnetik. Dengan adanya e-Modul ini diharapkan nantinya mahasiswa dapat menghitung secara tepat besar dari medan magnetik dan menghubungkan kuat medan tersebut dengan perangkat elektronika Motor Listrik.
\end{abstract}

Kata Kunci : e-Modul, medan elektromagnetik, motor listrik

\section{Pendahuluan}

Pendidikan adalah hal yang sangat penting untuk mendukung kehidupan manusia. Terdapat dua jenis pendidikan yang kita kenal, yaitu pendidikan formal dan pendidikan non formal. Baik pendidikan formal maupun non formal keduanya tidak pernah lepas dari proses pembelajaran. Dimana proses pembelajaran ini mempunyai peran yang penting dalam menghasilkan lulusan berkualitas. Kualitas suatu lulusan perguruan tinggi dipengaruhi oleh beberapa faktor, diantaranya pengajar (dosen), penggunaan metode mengajar yang menarik dan bervariasi, perilaku belajar peserta didik yang positif, suasana belajar yang kondusif dan penggunaan perangkat pembelajaran yang tepat dalam mendukung proses belajar.

Motivasi mahasiswa untuk mempelajari tentang materi Teori Medan cukup rendah. Hal ini terlihat darihasil evaluasi belajarpada tahun ajaran sebelumnya. Hasil eveluasi terhadap mahasiswa Program Studi Pendidikan Teknik Elektro semester 3 tahun akademik 2015/2016 menunjukkan bahwa rata-rata hasil belajar pada mata kuliah Teori Medan masih rendah $(67,85)$. Disamping itu hasil wawancara juga menunjukkan bahwa mata kuliah Teori Medan Elektromagnetik merupakan mata kuliah yang sulit dipahami.

Standar Kompetensi pada akhir mata kuliah Teori Medan adalah kemampuan mahasiswa dalam menganalisis sebuah piranti elektronika dalam hal ini sebuah motor listrik, dan menghubungkannya dengan konsep dasar teori medan yang telah dipelajari. Dasar-dasar medan listrik dan magnet, aplikasi medan listrik dan medan magnet pada piranti elektronika, teorema-teorema yang ada di dalamnya, serta pengaruh sebuah medan magnet pada kecepatan putar motor listrik. Berdasarkan pengkajian tim rumpun, konten untuk mata kuliah Teori Medan sebagian besar memperkenalkan persamaan yang bersifat abstrak, sehingga dosen membutuhkan waktu yang lama untuk menjelaskan materi. Dibutuhkan media e-Modul yang dapat mengubah pengetahuan/informasi yang abstrak menjadi riil sehingga mahasiswa lebih mudah dalam memahami konsep.

Pada penelitian ini akan lebih difokuskan pada materi tentang hukum Biot-Savart. Pemilihan bab hukum Biot-Savart mengacu pada keterkaitan yang lebih dekat antara medan 
magnetik dengan beberapa piranti elektronika (misal motor listrik dan generator). Dengan memahami secara lebih detail maka mahasiswa dapat lebih mudah menghubungkan antara sebuah konsep dasar, persamaan matematis, dan sebuah piranti elektronika.

Media e-Modul merupakan sebuah solusi alternatif untuk menyelesaikan masalah tersebut. Dengan menggunakan media e-Modul yang dapat diakses melalui smartphone, memungkinkan mahasiswa untuk dapat melakukan interaksi dengan sumber ajar dan dapat belajar mandiri dimanapun, karena hampir sebagian besar mahasiswa menggunakan smartphone sebagai sarana komunikasi. Untuk aplikasi komputer yang dapat digunakan adalah Adobe Flash 5.0 yang dikombinasikan dengan adobe air untuk lebih mendukung pada sistem android.

Penelitian ini bertujuan untuk mengetahui seberapa besar tingkat efisiensi dari media e_Modul. Efisiensi dari media nantinya dapat dilihat dari tingkat kelayakan (melalui kategori gain). Dengan demikian jika hasil telah diperoleh dan diketahui maka dapat ditentukan langkah apa yang selanjutnya akan diambil.

\section{Teori}

Berdasarkan penjelasan dari Tan dan Gagne pengertian belajar adalah sebuah aktivitas mental atau psikis yang dilakukan oleh seseorang sehingga menimbulkan perubahan tingkah laku yang berbeda antara sesudah belajar dan sebelum belajar. Dalam proses belajar dan mengajar salah satu unsur pendukung yang sangat penting adalah penentuan jenis media pembelajaran yang sesuai dengan materi ajar. Media pembelajaran merupakan sebuah alat atau sarana untuk melakukan komunikasi agar dapat menyampaikan informasi tentang sebuah hal dengan jelas. Adanya media pembelajaran ini dimaksudkan agar dapat mempermudah proses belajar mengajar, sehingga proses belajar mengajar menjadi lebih efektif dan efisien.

Terdapat berbagai jenis media pembelajaran. Salah satu media pembelajaran yang dapat digunakan adalah modul. Modul merupakan suatu paket pengajaran yang memuat suatu unit konsep dari bahan pengajaran. Pengajaran modul merupakan suatu usaha penyelenggaraan pembelajaran individual yang memungkinkan siswa menguasai suatu unit bahan pelajaran sebelum dia beralih ke unit berikutnya. Sehubungan dengan teknologi yang semakin canggih dan mudah didapat dengan harga terjangkau pada saat ini modul yang pada umumnya disajikan dalam wujud cetakan maka dengan menggunakan teknologi elektronik menggunakan komputer modul dapat disajikan dalam bentuk digital atau disebut dengan eModul. (Vembriato, 1987:20). Salah satu jenis modul adalah E-Modul yang merupakan sarana pembelajaran yang berisi materi, metode, batasan-batasan, dan cara mengevaluasi yang dirancang secara sistematis dan menarik untuk mencapai kompetensi yang diharapkan sesuai dengan tingkat kompleksitasnya secara elektronik (bagian dari e-learning). e-Modul yang dirancang dalam bentuk digital dan sistematis dapat mendukung siswa agar dapat belajar mandiri. Hal tersebut membuat siswa dituntut untuk belajar memecahkan masalah dengan caranya sendiri.

Modul dalam sebuah proses pembelajaran diharapkan dapat mencapai pada tujuan yang diharapkan. Dimana diharapkan mahasiswa mampu memahami sesuatu berdasarkan pengalaman belajarnya. Sebagai contoh dalam pembelajaran yang menggunakan konsep matematis. Salah satu aspek yang masih perlu dikembangkan dalam mempelajari matematika adalah kemampuan pemahaman matematis. Pemahaman matematis ada yang disebut kemampuan pemahaman instrumental, kemampuan pemahaman relasional. Pemahaman relasional memiliki tingkat yang lebih tinggi dibanding dengan pemahaman instrumental. 
Baik pemahaman instrumental maupun pemahaman relasional perlu ditingkatkan pada pembelajaran matematika (Abd. Qohar, 2009).

Berdasarkan pendapat yang telah disampaikan, maka dapat disimpulkan bahwa pemahaman konsep matematis adalah tingkat kemampuan siswa memahami sebuah objek matematis dan mampu menghubungkannya dengan objek lain yang sejenis maupun tidak sejenis, dimana pemahaman tersebut harus meliputi pemahaman secara instrumental maupun relasional. Dengan demikian siswa dapat menyampaikan kembali menggunakan kalimat sendiri.

\section{Metode Penelitian}

Jenis penelitian ini merupakan penelitian pengembangan untuk mengembangkan dan mengimplementasi produk yang dihasilkan. Produk yang dihasilkan berupa media e-Modul pada smartphone pokok bahasan torsi magnetik. Desain Penelitian yang dikembangkan adalah model ADDIE (Analysis, Design, Development, Implementation, dan Evaluation (Lee \& Owens ,2004). Model pengembangan ADDIE terdiri dari 5 tahap, yaitu analisis (analysis), perancangan (design), pengembangan (development), Implementasi (implementation), Evaluasi (evaluation).

\section{Hasil Penelitian dan Pembahasan}

Penelitian yang dilakukan terfokus pada kemampuan analisis mahasiswa tentang hubungan antara kuat medan magnetik yang telah diperoleh dari hasil perhitungan dengan perangkat motor listrik. Uji coba pertama telah dilakukan, dimana mahasiswa diberikan sebuah kit praktikum elektronika dan sebuah motor listrik. Melalui kit praktikum tersebut mahasiswa harus mencocokkan terlebih dahulu kuat medan magnet hasil perhitungan dan hasil pengukuran.

Berdasarkan hasil penelitian yang telah dilakukan, diperoleh hasil seperti pada tabel berikut :

\begin{tabular}{|c|l|c|c|c|}
\hline \multirow{2}{*}{ No } & \multicolumn{1}{|c|}{ Aspek yang Diteliti } & \multicolumn{2}{c|}{ Hasil } \\
\cline { 3 - 5 } $\mathbf{1}$ & $\begin{array}{l}\text { Kemampuan mahasiswa mendapatkan nilai kuat } \\
\text { medan magnet secara perhitungan dengan } \\
\text { melakukan perubahan terhadap variabel arus, } \\
\text { jarak, dan lilitan. }\end{array}$ & $26,6 \%$ & $86,67 \%$ & 0,6 \\
\hline $\mathbf{2}$ & $\begin{array}{l}\text { Kemampuan mahasiswa menjelaskan hubungan } \\
\text { antara kuat medan magnet dengan sistem kerja } \\
\text { motor listrik }\end{array}$ & $20,0 \%$ & $66,7 \%$ & 0,4 \\
\hline $\mathbf{3}$ & $\begin{array}{l}\text { Kemampuan mahasiswa menganalisis sebuah } \\
\text { kasus matematis yang menghubungkan antara } \\
\text { motor listrik dan kuat medan magnet. }\end{array}$ & $20,0 \%$ & $78,3 \%$ & 0,5 \\
\hline
\end{tabular}

Tabel 1 menjelaskan bahwa sebelum menggunakan e-Modul prosentase jumlah mahasiswa yang mampu dalam menganalisis dan menjelaskan tentang hubungan dari kuat medan magnet dengan motor listrik sebesar 26,6\% atau jika dikonversi ke dalam jumlah mahasiswa hanya sebanyak 4 orang mahasiswa saja. Setelah diberikan e-Modul untuk pembahasan tentang hukum Biot-Savart jumlah mahasiswa yang mampu 
menghitung dan mengukur kuat medan magnet mengalami peningkatan mencapai 86,67\% atau sebanyak 13 mahasiswa. Dua orang mahasiswa masih belum mengalami peningkatan kemampuan. Hal tersebut dikarenakan untuk menghitung kuat medan magnet mahasiswa harus mengkonversi beberapa satuan terlebih dahulu menjadi satuan yang lain.

Kedua adalah kemampuan mahasiswa menjelaskan hubungan antara kuat medan dengan sistem kerja motor listrik. Beberapa mahasiswa mampu memberikan penjelasan tentang sistem kerja motor listrik. Dari hasil perhitungan dan pengukuran yang telah diperoleh mahasiswa diminta untuk memberikan penjelasan tentang hubungan antara kuat medan dengan sistem kerja motor listrik secara tertulis. Hasil yang diperoleh belum menunjukkan peningkatan yang begitu signifikan. Hal tersebut dikarenakan analisis yang dilakukan harus sangat detail, dan kemampuan mahasiswa dalam hal perhitungan matematis masih cukup rendah.

Kasus yang ke tiga adalah kemampuan mahasiswa dalam menghubungkan antara motor listrik dengan medan magnet. Mahasiswa menjelaskan pengaruh kuat dan lemahnya medan magnet terhadap kecepatan sudut motor listrik. Semakin besar kecepatan sudut maka putaran motor akan semakin cepat.

\section{Daftra Pustaka}

[1] Kurniadi. 2008. Mengurangi Miskonsepsi Dinamika Dengan Konflik Kognitif Melalui Metode Demonstrasi. Jurnal Pendidikan IKIP PGRI Madiun Vol.14, No.1 Juni 2008.

[2] Handhika et al. 2014. Pengembangan Media Pembelajaran Bermuatan Konflik Kodnitif untuk Mengurangi Dugaan Miskonsepsi pada Mata Kuliah Fisika Dasar. Jurnal Materi dan Pembelajaran Fisika. Vol. 4 No. 2.

[3] Aydin G. \& Balim A. G. 2010. The Activities Based on Conceptual Change Strategies Prepared by Science Teacher Candidates. Western Anatolia of Education Sciences (WAJES), Dokuz Eylul University Institute, Izmir, Turket ISSN 1308-8971.

[4] Clement J., Brown E. D., \& Zietsman A. 1989. Not All preconceptions are Misconceptions: finding 'anchoring conceptions' for grounding instruction on students' intuitions. Int. J. Sci. EDUC., vol 11, special issue,554-565.

[5] T. Charitat and F. Graner. 2003. About the Magnetic Field of a Finite Wire. European Journal of Physics. 24 (2003) 267-270.

[6] Herman A. Haus and James L. Melscher. 1998 Electromagnetic Field and Energy. Massachusetts Institute of Technology.

[7] Rustam Efendi et al. 2007. Medan Elektromagnetika Terapan. Jakarta: Erlangga.

[8] I. Prastyaningrum \& S. Kartikaningsih. 2016. Approximate theory the Electromagnetic Energy of Solenoid in Special Relativity. J. Phys.: Conf. Ser. 795012034.

[9] Branca, N. A. "Problem solving as a goal, process, and basic skill" dalam Krulik, S. \& Reys, R. E. (editor). 1980. Problem-solving in school mathematics. New York: The National Council of Teachers of Mathematics, Inc. 